\title{
ФІЛОСОФСЬКО-МЕТОДОЛОГІЧНІ ЗАСАДИ ПРОФЕСІЙНӦ̈ ПІДГОТОВКИ МАЙБУТНІХ ФАХІВЦІВ СОЦІОНОМІЧНИХ ПРОФЕСІЙ
}

І. М. Мельничук

ДВНЗ “Тернопільський державний медичний університет імені І. Я. Горбачевського МОЗ Украйни”

\section{PHILOSOPHICAL AND METHODOLOGICAL BASIS OF FUTURE SOCIONOMIC SPECIALISTS PROFESSIONAL TRAINING}

\author{
I. M. Melnychuk \\ SHEI "Ternopil State Medical University by I. Ya. Horbachevsky of MPH of Ukraine"
}

\begin{abstract}
У статті розкрито сутність філософських принципів і загальнонаукових методологічних підходів у дослідженні професійної підготовки майбутніх медичних працівників.
\end{abstract}

The essence of general philosophical principles and methodological approaches in research training of future medical workers is revealed in the article.

Вступ. Дослідження філософсько-методологічних засад професійної підготовки майбутніх фахівців соціономічних професій, до яких належать і дипломовані медичні працівники, грунтується на філософських принципах і загальнонаукових методологічних niдxодax аналізу соціуму й особистості, освітніх процесів у ВНЗ та професіогенезу студентів на шляху формування у них професійної компетентності. Симбіоз філософських принципів і загальнонаукових підходів у медичній педагогіці відображає сутність філософсько-методологічних засадпрофесійної підготовки майбутніх фахівців медицини як представників однієї із соціономічних професій.

Основна частина. Розкриємо сутність філософських принципів і загальнонаукових підходів у дослідженні професійної підготовки майбутніх медичних працівників.

Принцип об'єктивності заснований на визнанні професійної діяльності медичних працівників як дійсності в ії реальних закономірностях і всезагальних формах. Основний зміст цього принципу у медичній педагогіці відображається в таких вимогах:

- виходити з практичної цілеспрямованої діяльності на основі використання досвіду роботи фахівців медицини, враховуючи об' єктивний характер явищ i подій, які відбуваються, з одного боку, в медичній сфері, а з іншого - в процесі професійної підготовки майбутніх медичних працівників;

- усвідомлювати й реалізовувати активну роль студента як суб' єкта пізнання і діяльності, оскільки фор- мування професійної компетентності - “це завжди включення нових знань в структуру вже наявних (актуалізованих) знань" [7, с. 9];

- виходити з фактів у їх сукупності й уміти відображати логіку речей у логіці понять, адже опертя на об'єктивні закони розвитку природи, суспільства й особистості дає змогу передбачати і обгрунтовувати появу нових явищ, котрі можуть використовуватися в практичній діяльності майбутнього медичного працівника у процесі виконання ним професійних функцій;

- генерувати адекватну систему методів послідовної підготовки майбутніх медичних працівників, що надає науковому пізнанню і педагогічним технологіям навчання фахівців "необхідної цілісності та єдності, перетворюючи науку в систему об'єктивно істинних і логічно пов'язаних понять, суджень, законів і теорій" [7, c. 11];

- розглядати цю систему у відповідному соціокультурному контексті, в межах певних світоглядних орієнтацій, спрямованих на пошук нових істин про навколишній світ, враховуючи висновки найновіших комплексних наук, що виникли наприкінці XX ст. (інформатики, синергетики, теорії систем);

- підходити до всіх процесів і явищ у навчанні медичних працівників конструктивно-критично, що передбачає організацію професійної підготовки студентів до фахової діяльності у відповідності до логіки як процесу навчання, так і професійної діяльності у сфері медицини. 
Основними філософськими категоріями, які використовуються в процесі реалізації цього принципу, є: детермінізм (філософське вчення про об'єктивний закономірний взаємозв'язок і причинну зумовленість усіх явищ); діалектична логіка (наука про закони і форми відображення в мисленні розвитку об'єктивного світу й пізнання); істина - правильне, адекватне відображення предметів і явищ дійсності суб'єктом, що їх пізнає (найвищим критерієм істини є об'єктивне буття, “дійсність”, практика); життя як первинна реальність; людина як соціальна істота з іiі світоглядом і різними формами світорозуміння (міфологічним, релігійним, науковим і філософським), внутрішнім Я, самоусвідомленням і самоідентичністю, інтелектом і духовністю, що дозволяє розрізняти добро і зло, аналізувати історію розвитку суспільства, розуміти майбутнє, тобто те, чого ще не існує; особистість, котра є “центром духу" і будує особливе “поле взаємовідносин із середовищем" [9, с. 59]; бідність як показник економічного становища і рівня життя людини в суспільстві [8, с. 45]; мораль як форма суспільної свідомості, сукупність принципів, правил, норм, якими керуються люди у своїй поведінці, створюючи моральні норми і моральні закони, обов' язкові для кожної людини [8, с. 243]; діяльність як форма активності людини, що виявляється у цілеспрямованій зміні та перетворенні світу й людської свідомості та ін.

Принцип конкретності грунтується на філософській категорії, що відображає систему взаємозв'язаних речей у сукупності всіх їі сторін і зв'язків на емпіричному етапі як чуттєво-конкретне, а на теоретичному етапі - як мисленнєво-конкретне. Розгортання принципу конкретності потребує оперування такими філософсько-методологічними категоріями і поняттями, що дозволять:

- “вивести” певне явище, зокрема, педагогічний процес підготовки майбутніх медичних працівників до професійної діяльності, з його субстанційної ознаки, тобто головної, суттєвої властивості професійної діяльності взагалі й підготовки фахівців у ВНЗ, та відтворити цей процес як діалектично розокремлене ціле;

- врахувати різноманітні умови (педагогічні, психологічні, соціальні, особистісні тощо) та інші фактори, що впливають на процес професійної підготовки майбутніх медичних працівників;

- виявити специфічний механізм взаємозв'язку загального (наприклад, основ загальної педагогіки) й одиничного (зокрема, галузей педагогічного знання, до яких відноситься і медична педагогіка);
- розглянути досліджуваний предмет (процес підготовки медичних працівників) у межах ширшого (більшого) цілого, елементом якого він є (підготовка фахівців у вищих навчальних закладах і до професійної діяльності).

Основними методами реалізації цього принципу є: дедукиія (метод пізнання, заснований на висновках від загального до часткового (особливого)), індукичія (метод пізнання, згідно з яким на основі висновків про часткове роблять висновки про загальне), інтеграція (процес і результат взаємодії елементів, в результаті чого формується зінтегрований об'єкт (система).

Принцип історичності (історизму) - філософський, діалектичний принцип, який є методологічним вираженням саморозвитку дійсності у вигляді цілісної безперервної єдності таких станів (часових періодів), як минуле, теперішнє і майбутнє цього феномену. Цей принцип включає в себе такі вимоги: 1) розгляд генези головних етапів історичного руху трансформацій медичної освіти з метою реконструкції минулого; 2) вивчення сучасного стану професійної підготовки фахівців медицини до надання медичної допомоги на відповідному рівні фахової компетентності; 3) удосконалення методик підготовки медичних працівників.

Принцип історизму пов'язується з конкретно-історичним ракурсом дослідження педагогічних явищ у медицині. Історіографічний аналіз феномену медичної педагогіки сприяє накопиченню й опису конкретних фактів їі розвитку. Їх структурування й упорядкування уможливлюється завдяки використанню логічних процедур аналізу з метою визначення оптимальних шляхів професійної підготовки майбутніх медичних працівників.

Дослідження проблеми професійної підготовки медичних працівників потребує вивчення, систематизації наукових знань із цієї проблеми в ретроспективі. Це дає змогу перейти від емпіричного описання фактів підготовки медичних працівників до теоретичного узагальнення і виявлення еволюції наукових уявлень та поглядів на зміст і сутнісні характеристики цього процесу, що є новим рівнем інтеграції наукового знання у вивченні медичної педагогіки.

З принципами об'єктивності, конкретності та історичності тісно пов'язаний принцип науковості, що передбачає реалізацію здатності людини використовувати особливий інструмент людського пізнання понятійне мислення. Саме специфіка понятійного мислення дозволяє студентам проникати у приховані, внутрішні, сутнісні властивості процесів та явищ у фаховій роботі медичного працівника. Якщо освоєн- 
ня світу відбувається в межах безпосередньої практичної діяльності, то наукове пізнання відбувається шляхом створення особливих абстракцій (форм пізнання, що базуються на подумки уявлюваному виокремленні істотних властивостей і зв' язків предмета) та ідеалізацій (процесів уявного конструювання понять про об' єктивні процеси і явища), що актуалізує включення студентів у віртуально-професійні ситуації під час навчання.

Наукове понятійне мислення (теоретичне, систематизоване) дає змогу здійснити теоретичні узагальнення. У ході реалізації цього принципу відбувається генерування нових знань у вигляді принципово нових ідей 3 використанням таких категорій і понять, якими оперують як медики, так і педагоги - фахівці підготовки майбутніх медичних працівників.

Основними філософсько-методологічними категоріями і поняттями в реалізації цього принципу є: аналогія (подібність, схожість різних предметів за певними ознаками), верифікація (спосіб установлення істинності наукових тверджень), впорядкованість (поява відношення порядку між елементами, що створює додаткову ознаку для їх об'єднання в систему), генералізачія (узагальнення, логічний перехід від конкретного до загального), умовивід (форма мислення, коли 3 одного чи кількох суджень постає нове судження, яке містить нове знання про предмет) та ін.

Принцип науковості пов' язаний 3 філософським принципом конкретності та загальнонауковим принципом системності або системним підходом. Не менш важливою засадничою ідеєю, що формується в процесі пізнання сутності фахової роботи медичного працівника і сприяє пошукам оптимальних методик їх професіоналізації, є принцип протиріччя.

Сутність принципу протиріччя або суперечності трактується як становище, за якого що-небудь одне виключає інше, несумісне з ним або протилежне до нього, чи заперечує його [1, с. 1415]. Якщо розглядати медичну педагогіку на основі принципу суперечності, то цей феномен існує як реальність (медицина і педагогіка - це різні наукові напрямки, однак підготовка медичних працівників базується на педагогічних закономірностях, принципах, методах і формах навчання); реалізується як теорія і практи$\kappa a$ (у вигляді методики підготовки майбутніх медичних працівників); $є$ інтегративною навчальною дисципліною (предметом вивчення). Існує логічний зв' язок принципу суперечності з принципом детермінізму (спричинення).

Принцип детермінізму (англ. determinism, від лат. determino - визначати [6, с. 188]) розглядають як систему поглядів про об'єктивний, закономірний зв' язок і всезагальну зумовленість усіх явищ навколишнього світу. Зв'язок категорій закономірності і причинності полягає у визначенні об'єктивних закономірностей і причинно-наслідкової зумовленості професійної підготовки фахівців медицини в сучасних умовах розвитку суспільства. У наукових дослідженнях детермінізм визначається як вроджена здатність людської свідомості зв’ язувати явища в причинні ланцюжки. Це актуалізує застосування у підготовці майбутніх медичних працівників таких педагогічних технологій, за допомогою яких студенти матимуть змогу дати теоретичне обгрунтування причин і наслідків своїх дій, наприклад, у змодельованих віртуально-професійних ситуаціях.

Категорії причини і наслідків, відображаючи об'єктивну генетичну зумовленість усіх явищ, виступають одночасно ступенями розвитку пізнання й логічними формами мислення. Пізнання причин - один iз найглибших і фундаментальних рівнів руху дослідницької думки, що має враховуватися у підготовці майбутніх медичних працівників.

У загальній формі принцип причинності методологічно орієнтує майбутніх медичних працівників на підняття пізнання за певними причинно-наслідковими щаблями, на основі аналізу їх перетинів і взаємодій. Важливість цього завдання у медичній педагогіці полягає в тому, щоб навчити студентів-медиків виокремлювати такі основні риси причинно-наслідкового зв' язку, як породження одного іншим (найбілыш суттєва, субстанційна ознака), об'єктивність, всезагальність, необхідність, безконечність, неперервність у часі та просторі. Адже одна й та ж причина за різних умов викликає неоднакові наслідки, що повинні враховувати медичні працівники у своїй професійній діяльності.

Отже, дотримання філософських принципів передбачає цілісне формотворення педагогічної системи професійної підготовки фахівців медицини як результату історії пізнання цього феномену й реалізації загальнонаукових підходів до професіогенезу майбутніх медичних працівників.

Структуруючи систему загальнонаукових підходів до професійної підготовки майбутніх медиків, ми виокремлюємо:

Гносеологічний підхід, який грунтується на теорії пізнання (гносеологіi), тобто вченні про знання - процесі, зумовленому суспільно-історичною практикою набуття і розвитку знання, його постійного поглиблення, розширення й удосконалення. Це така взаємодія об'єкта та суб'єкта, результатом якої є нове 
знання. Філософсько-діалектичне розуміння пізнання потрібно розглядати не як дзеркальне відображення, пасивне споглядання світу окремим суб'єктом (“гносеологічним Робінзоном”) [9], а як складний, діалектичний, соціокультурно зумовлений процес активного творчого відображення дійсності в ході соціально-історичної практики, зокрема практики підготовки медичних працівників.

В основі гносеологічного підходу лежить спрямованість на застосування в роботі та підготовці медичного працівника форм і методів наукового пізнання, всебічного вивчення, аналізу, порівняння, знаходження паралелей у соціально-історичних особливостях процесів, які відбуваються в медицині та в педагогіці, що сприяє встановленню закономірностей їх перебігу, визначенню специфіки і тенденцій розвитку. Під час професійної підготовки майбутні медичні працівники безпосередньо в практичній діяльності долають обмеженість внутрішнього досвіду, а отримане знання “піднімається” до рівня об'єктивно-істинного. Адже освіта полягає не в кількості знань, а в повному розумінні й умілому застосуванні всього того, що знаєш (А. Дістервег).

Основна ідея системного підходу полягає у вивченні об'єкта як цілого, що складається з різних взаємопов' язаних елементів, упорядкованого та складно організованого. Наукова цінність системного підходу полягає в тому, що відображається світоглядний рівень дослідження, є універсальним методом пізнання, технологією дослідження, що протистоїть стихійності, суб' єктивізму, створює умови для послідовності і стабільності наукових пошуків [3]. Системний підхід визначається як напрямок у спеціальній методології науки, завданням якого є розробка методів дослідження і конструювання складних за організацією об'єктів як систем. На думку вчених-системологів, будь-яка система характеризується впорядкованістю зв'язків і відносин між складовими, компонентами, елементами, а також їх цілісністю, інтегративністю, що має особливості в різних системних об'єктах. Відношення частин до цілого знаходиться у складних взаємозв'язках: усяка зміна властивостей одного з елементів викликає зміну й інших компонентів, а можливо, й усієї системи. Поява нових зв'язків між елементами приводить до виникнення інтегративних властивостей окремих компонентів, тому важливою характеристикою будь-якої системи є виокремлення особливих системоутворювальних зв'язків.

Зокрема, професійна підготовка медичного працівника розширює бачення цієї системи за рахунок розвитку уявлень про цілісність, системний характер набуття професії та здійснення професійної діяльності, що підкреслює взаємозв'язок трьох систем: цілісної педагогічної системи підготовки майбутніх медиків у ВНЗ, системи навчання студентів фахових дисциплін та системи практичної діяльності фахівця медицини.

Комплексний підхід спрямований на інтеграцію знань про різноманітні якості, властивості і стани різних систем (соціальної, наукової, освітньої, професійної), в яких відбувається підготовка і власне професійна діяльність медичного працівника. Загальними характеристиками комплексного підходу є: спрямованість на виявлення багатоаспектності, багатофакторності, різнорідності онтологічних детермінант і складових. У гуманітарних дисциплінах орієнтація на комплексність досліджень привела до появи нової наукової галузі - людинознавства, що покликане створити цілісний інтегративний підхід до вивчення людини. Саме фундаментальна категорія філософії “людина” є смисловим центром практично будь-якої філософської системи. Розгляд людини в контексті широких соціальних зв' язків акцентує увагу на активності суб' єкта, коли відбуваються трансформаційні процеси в ході предметно-практичної діяльності людини.

Характерною особливістю пізнавального процесу початку XXI ст. є посилення ролі міждисциплінарних комплексних підходів до професійної підготовки фахівців. Зокрема, у процесі вивчення особистості майбутнього фахівця теорія пізнання спирається на дані психології, фізіології, нейрофізіології, медицини. Різноманітний матеріал для узагальнювальних висновків запозичується 3 математики, кібернетики, синергетики, акмеології, природничих і гуманітарних наук у вигляді сукупності різноманітних дисциплін, а також історії, філософії та медичної педагогіки.

Використання наукових положень і висновків суміжних наукових галузей дають змогу розглядати явище професійної підготовки фахівців соціономічних професій комплексно в системі наук та цілеспрямовано обирати певну сукупність теоретико-методологічних підходів, які відображають сучасний рівень наукових знань, дають змогу теоретично обгрунтувати шляхи емпіричного дослідження, сприяють підвищенню ефективності професійної підготовки майбутніх медиків.

Oсобистісний підхід відображає факт “включеності” суб'єкта в соціальні зв' язки та взаємини, трактує людину як соціокультурну реальність. Вплив соціальних факторів на розвиток особистості відбувається через іiі суб'єктивний світ як результат тієї внутрішньої роботи самої особистості, в процесі якої 
зовнішнє, проходячи через внутрішнє, переробляється, освоюється і використовується людиною у практичній діяльності. Тому особистість є суб'єктом пізнання й активного перетворення світу.

Основним поняттям у реалізації особистісного підходу є дефініція “особистість”, яка вивчається спеціальною наукою персонологією (лат. persona особа) та іншими сучасними суспільними науками (психологією, педагогікою, акмеологією тощо). Особистість розглядається як цілісність - динамічна, відносно стабільна, цілісна система інтелектуальних, соціально-культурних, морально-вольових якостей людини. Діалектична єдність загального, особливого й окремого виникає не із зовнішньої, а з внутрішньої доцільності, шляхом перетворення культури, що освоюється, на живу індивідуальну творчу діяльність. Це особлива якість людини, що набувається нею в процесі діяльності, спілкування і взаємин, виникає як засіб, інструмент для знаходження людиною своєї сутності, є суб'єктом пізнання й активного перетворення світу. Цілісна особистість $є$ не просто механічною сумою субособистостей, а розглядається як суб'єкт власної життєдіяльності, що включає всю повноту змісту індивідуального життя в реальному культурно-історичному контексті. Зріла особистість функціонально автономна, з усвідомленою, мотивованою поведінкою, має широкі межі “я”, здорове почуття реальності й потребу самовдосконалення.

Підготовка студентів на основі особистісно-орієнтованого навчання характеризується як така, що відбувається на засадах всебічного врахування індивідуальних потреб і можливостей студента, ставлення до нього як до свідомого й відповідального суб' єкта навчально-виховної взаємодії з викладачем і ровесниками. Дидактико-методичне забезпечення особистісно-орієнтованого навчання передбачає посилення у змісті професійної підготовки студентів людинознавчого, особистісно значущого, емоціогенного матеріалу, створення методик на засадах діалогічної взаємодії, пізнавального інтересу, ситуації вибору, рефлексії, стимулювання, збереження емоційної комфортності та реалізації “педагогіки успіху” [4, с. 627]. Метою реалізації особистісного підходу є створення умов (змісту, методів, інноваційно-технологічного навчального середовища) для індивідуальної самореалізації студента, його професійного зростання і саморозвитку у формуванні професіоналізму. Діяльнісний підхід грунтується на твердженні, що тільки завдяки діяльності особистість стає суб'єктом пізнання та перетворення об'єктивної дійсності. Пізнання, мислення - це завжди пошуки і відкриття нового, раніше невідомих підходів і рішень, активне досягнення істини, активна діяльність суб'єкта в будь-якій їі формі. Діяльність - одне з фундаментальних понять класичної філософської традиції, що фіксує у своєму змісті акт зіткнення цілепокладальної (свобідної) волі, з одного боку, і об'єктивних закономірностей буття - 3 іншого. Відповідно до цього в структурі діяльності традиційно виокремлюються суб' єктний компонент, тобто цілепокладальний суб' єкт, і об'єктний компонент, що є предметом діяльності $[5$, c. 311$]$.

Отже, набуття студентами вмінь виконувати професійну діяльність має особистісно-неповторний характер, що зумовлюється опертям не тільки на результати теоретичної підготовки, але й на особистісні моделі образного уявлення результатів професійної діяльності. Зміст цих моделей залежить від “поля особистісних смислів" [7], які формуються в конкретного суб'єкта - майбутнього фахівця, котрий структурує свою діяльність неповторно на основі особистого бачення себе в професії, сформованих ціннісних орієнтацій тапрофесійної самоідентифікації.

Єдність свідомості (внутрішнього світу почуттів, думок, ідей та інших духовних феноменів) і діяльності людини належить до “вічних” філософських проблем, що їх розкриває філософська антропологія. Згідно з принципом єдності свідомості і діяльності майбутні медики ще в період навчання у ВН3 мають усвідомлювати мету своєї професійної діяльності, планувати й організовувати свою роботу, усвідомлювати особистісну значущість іï результатів. Відтак цей принцип тісно пов' язується з праксеологічним підходом.

Праксеологічний nidxid (грец. praxis - дія) грунтується на філософській концепції діяльності, що на сьогодні має статус програмно-концептуального проекту і презентує загальну теорію організації діяльності польського філософа ілогіка Т. Котарбіньського (18861981). Праксеологічний підхід стосується як організації навчально-пізнавальної діяльності суб' єктів освітнього процесу, такі оптимізації майбутньої професійної діяльності фахівців медицини, моделі якої вони апробують ще під час навчання у ВНЗ.

Тому особливої уваги у розкритті філософських принципів та загальнонаукових підходів дослідження соціальної роботи заслуговують аксіологічний, акмеологічний та синергетичний підходи, які тісно взаємопов'язані між собою і тому потребують більш грунтовного розгляду в окремих публікаціях.

Висновок. Професійна підготовка майбутніх фахівців соціономічних професій, до яких відносять- 
ся і медичні працівники, грунтується на філософськометодологічних засадах - філософських принципах i загальнонаукових методологічних підходах до навчання студентів у ВНЗ. Дотримання філософських принципів (об'єктивності, конкретності, історичності, науковості, протиріччя, детермінізму) і системи загаль-

\section{Література}

1. Великий тлумачний словник сучасної української мови / уклад. і голов. ред. В. Т. Бусел. -К. ; Ірпінь : ВТФ “Перун”, 2009. - 1736 c.

2. Гончаренко С. У. Український педагогічний словник / С. У. Гончаренко. -К. : Либідь, 1997.-376 с.

3. Гузій Н. В. Категорія професіоналізму в теорії і практиці підготовки майбутнього педагога : дис. ... доктора пед. наук : 13.00.04 / Наталія Василівна Гузій ; КПУ ім. М. П. Драгоманова. - Київ, 2007. - 577 с.

4. Енциклопедія освіти / Акад. пед. наук України ; голов. ред. В. Г. Кремень. - К. : Юрінком Інтер, 2008. - 1040 с.

5. Новейший философский словарь / сост. и глав. ред. А. А. Грицанов. - [3-е изд., исправл.]. - Мн. : Книжный Дом, 2003.-1280 с. - (Мир энциклопедий). нонаукових підходів (гносеологічного, системного, комплексного, особистісного, діяльнісного, єдності свідомості та діяльності, праксеологічного, аксіологічного, акмеологічного та синергетичного) передбачає цілісне формотворення педагогічної системи професійної підготовки фахівців медицини.

6. Новий словник іншомовних слів : близько 40000 сл. і словосполучень / Л. І. Шевченко, О. І. Ніка, О. І. Хом'як, А. А. Дем'янюк ; за ред. Л. І. Шевченко. -К. : АРІЙ, 2008. $-672 \mathrm{c}$.

7. Методологія наукової діяльності : навч. посіб. / [Д. В. Чернілевський, О. М. Гандзюк, В. І. Захарченко та ін.] ; за ред. проф. Д. В. Чернілевського. - К. : Вид-во ун-ту "Україна", 2008. -478 с.

8. Соціологія : навч. посіб. / за ред. С. О. Макеєва. - [4-те вид., перероб. і доп.]. - К. : Т-во “Знання”, КОО, 2008. 566 с. -(“Вища освіта XXI століття”).

9. Философия : учеб. пособ. для высших учеб. завед. / отв. ред. д. филос. н., проф. В. П. Кохановский. - [8-е изд.]. Ростов н/Д: Феникс, 2004. - 576 с. 